\title{
Nematicidal Toxicity of Native Antagonists against Meloidogyne incognita
}

\author{
Arunima Bharali*, Bhabesh Bhagawati and Kurulkar Uday \\ Department of Nematology, Assam Agricultural University, Jorhat, India \\ *Corresponding author
}

\section{Keywords}

Purpureocillium

lilacinum, Pochonia

chlamydosporia,

Rhizobium sp.,

Azotobacter sp,

Bacillus megaterium,

Pseudomonas

fluorescens,

Meloidogyne

incognita, Culture

filtrate, LC50 and

LT50

Article Info

Accepted:

12 January 2019

Available Online:

10 February 2019

\section{A B S T R A C T}

An experiment was conducted to study the nematicidal toxicity of native antagonists against Meloidogyne incognita. For this the native antagonists viz., Pseudomonas fluorescens, Bacillus megaterium, Azotobacter sp., Rhizobium sp., Purpureocillium lilacinum and Pochonia chlamydosporia were screened against Meloidogyne incognita under in-vitro conditions. For this, four different concentrations of culture filtrates viz., 25, 50, 75100 percent were tested against $M$. incognita through egg hatch inhibition and second-stage juvenile's mortality at 24, 48, 72 and $96 \mathrm{hrs}$ of exposure time for each antagonist. The entire antagonists were also found to be effective in causing mortality of $\mathrm{J}_{2}$ with varying degrees at different concentrations of culture filtrates and at different exposure time. The relationship among the antagonists, concentration and time showed that all the tested antagonists were able to cause significant mortality of $M$. incognita $\mathrm{J}_{2}$ with increase in the concentrations of filtrates and time of exposure. The result of in-vitro test reveals that all the tested antagonists showed varied nature of egg hatch inhibition and juvenile mortality of $M$. incognita. However, among the tested antagonists $P$. fluorescens was found to be most effective in causing the highest egg hatch inhibition and $\mathbf{J}_{2}$ mortality of M. incognita in 25, 50, 75 and 100 per cent concentration of culture filtrates at 24, 48, 72 and $96 \mathrm{hrs}$ of exposure time. Further, probit analysis showed that culture filtrate of $P$. fluorescens exhibit either low $\mathrm{LC}_{50}$ values or less $\mathrm{LT}_{50}$ values against $\mathrm{J}_{2}$ of $M$. incognita in 25, 50, 75 and 100 percent concentration of culture filtrates at 24, 48, 72 and $96 \mathrm{hrs}$ of exposure time as compared to the others antagonists and found to be best native antagonists against $M$. incognita.

\section{Introduction}

The root-knot nematode Meloidogyne incognita is a common plant parasitic nematode in agricultural soil of Assam. It is a major pathogen on vegetables and other crop plants. However, it caused approximately 13.20 to 17.80 percent yield loss (Anon., 2011) in vegetable crops like tomato, brinjal, okra etc under Assam condition. Various pesticides of chemical origin have been used for controlling of this pest with remarkable results but the application of pesticides found toxic to the environment (Sahebani and Hadavi, 2008). The continuous application of such chemicals can alter the structure of ecology as a result create resistance in the target pests and showed their toxicity towards 
non-target organisms (Sánchez-Bayo, 2011). There are various ways to manage this pathogen but the application of native microorganism is prime importance because they share a similar environment with them and able to control the reproduction capacity of the target pathogen. Among these microorganisms, the fungi and bacteria are found to be effective because they exhibit with wide diversity (Kok et al., 2001) and their application is very easy as compared to other microorganisms. However, the efficacy of native antagonists is varied from species to species (Irving and Kerry, 1986) and further, a preliminary experiment is required to screen out the best antagonist. The microorganisms showed their antagonistic activity through the release of secondary metabolites in the surrounding environment towards pathogen and that reduced the viability of pathogen such as nematodes (Blaxster and Robertson, 1998 and Sharon et al., 2001). In the management of the plant-parasitic nematode, the application of culture filtrates of antagonist is the best method (Annapurna et al., 2018) for biological control of nematode. The potential benefits and fit fall must be examined so that effective native antagonist (s) can be utilized. Hence, a study was undertaken with the objective to study nematicidal toxicity of native antagonists against Meloidogyne incognita.

\section{Materials and Methods}

\section{Source and maintenance of $M$. incognita and antagonists}

M. incognita egg masses were obtained from infected brinjal plants, Department of Nematology, AAU, Jorhat-13 and pure culture were maintained on tomato in pots in the Net house, Department of Nematology, AAU, Jorhat-13. For in-vitro studies pure cultures of the antagonist viz., Pseudomonas fluorescens, Bacillus megaterium, Pochonia chlamydosporia and Purpureocillium lilacinum were obtained from Department of Plant Pathology, AAU, Jorhat-13 and Azotobacter sp. and Rhizobium sp. were obtained from Department of Soil science, AAU, Jorhat. The fungal antagonists were maintained on potato dextrose agar (PDA) and bacterial antagonists were maintained on nutrient agar (NA) at P.G Laboratory, Department of Nematology AAU, Jorhat.

\section{Collection of egg masses}

Egg masses were collected from the tomato plants maintained as pure culture. Roots were dissected with a sterilized dissecting needle and egg masses were handpicked from the galled roots with help of sterilized forceps. The picked egg masses were kept in sterilized cavity block containing $5 \mathrm{ml}$ sterilized water.

\section{Surface sterilization of egg masses}

The collected egg masses were surface sterilized in $0.4 \%$ sodium hypochlorite $(\mathrm{NaOCl})$ for two minutes (Singh and Mathur, 2010). Egg masses were washed thoroughly with sterile distilled water until the traces of $\mathrm{NaOCl}$ is removed and placed in cavity block for further use.

\section{Extraction of eggs from egg masses}

Surface sterilized egg masses were taken in a petri dish and subjected to $0.5 \% \mathrm{NaOCl}$ solution for two minutes, with frequent stirring followed by a 30 seconds settling to dissolve the gelatinous matrix. The eggs released through gelatinous matrix are further disinfested in $0.4 \% \mathrm{NaOCl}$ followed by three washings with sterile water. Eggs were then collected on a 500 mesh sieve and washed thoroughly with sterilized distilled water to remove the traces of $\mathrm{NaOCl}$. A measured quantity of suspension was prepared with eggs in the distilled water in a measuring 
cylinder. The egg suspension was prepared in such a way that $1 \mathrm{ml}$ of it contained 100 eggs. The counting of eggs in the suspension was made by using Hawkshley counting dish. Five aliquots of $1 \mathrm{ml}$ suspension were counted and their average number was multiplied with total volume of suspension prepared.

\section{Extraction of juveniles $\left(\mathrm{J}_{2}\right)$ from eggs}

For extraction of juveniles $\left(\mathrm{J}_{2}\right)$, the sterilized eggs were placed on a double layer tissue paper supported on a coarse aluminum wire mesh. This was placed over a $10 \mathrm{~cm}$ diameter petri dish filled with required quantity of water at $24-26^{\circ} \mathrm{C}$ in $\mathrm{BOD}$ incubator for hatching. Several such assemblies were maintained. The counting of juveniles in the suspension was made by using Hawkshley counting dish. Five aliquots of $1 \mathrm{ml}$ suspension were counted and their average number was multiplied with total volume of suspension prepared.

\section{Cleaning and sterilization of glasswares}

The glasswares used for different experiments were washed thoroughly with potassium dichromate $\left(\mathrm{K}_{2} \mathrm{Cr}_{2} \mathrm{O}_{7}\right)$ solutions, rinsed with water and glasswares were sterilized at $160^{\circ} \mathrm{C}$ for 2 hrs in hot air oven.

\section{Preparation of culture filtrates of fungal antagonists}

The ingredients used for preparation of potato dextrose broth (PDB) were peeled potato $(200 \mathrm{~g})$, dextrose $(20 \mathrm{~g})$ and distilled water $(1000 \mathrm{ml})$. Fully boiled potato extract was separated by using double layer muslin cloth and measured amount of dextrose was added to the extract. In another flask, remaining $500 \mathrm{ml}$ distilled water was taken and allowed agar-agar to melt by boiling. The molten agaragar was strained through double layer muslin cloth and mixed with potato extract solution.
The volume was made upto $1000 \mathrm{ml}$ by adding distilled water. $\mathrm{P}^{\mathrm{H}}$ of the medium was adjusted to 7.2. The medium was poured into $250 \mathrm{ml}$ Erlenmeyer flasks plugged by nonabsorbent cotton and then sterilized in autoclave at $121^{\circ} \mathrm{C}$ for 20 minutes. After $24 \mathrm{hr}$, the flask is seeded with fungal antagonists. The inoculated flasks were incubated at $25 \pm 2^{\circ} \mathrm{C}$ for 15 days in BOD incubator. Then fungal culture filtrates were obtained by filtering through Whatman filter paper no. 1. The filtrates so obtained were further centrifuged at $2000 \mathrm{rpm}$ to remove the extra spores and mycelia if any. Then supernatants were collected and used in the in-vitro studies.

\section{Preparation of culture filtrates of bacterial antagonists}

For the preparation of bacterial culture filtrates, 13 grams of nutrient broth (Himedia $M$ 244) were suspended in $1000 \mathrm{ml}$ of distilled water and heated up to boiling to dissolve the medium completely. The medium was poured into $250 \mathrm{ml}$ Erlenmeyer flasks plugged by non-absorbent cotton and then sterilized in autoclave at $15 \mathrm{lb}$ pressure $\left(121^{\circ} \mathrm{C}\right)$ for 15 minutes. After $24 \mathrm{hr}$, under sterilized condition the flask is seeded with bacterial antagonists. The inoculated flasks were incubated at $25 \pm 2^{\circ} \mathrm{C}$ for 15 days in BOD incubator. Then bacterial culture filtrates were obtained by filtering through Whatman filter paper no. 1. The filtrates so obtained were further centrifuged at $8000 \mathrm{rpm}$ to remove the cell if any. Then supernatants were collected and used in the in-vitro studies.

\section{Efficacy of culture filtrates of antagonists on hatching inhibition of Meloidogyne incognita eggs}

The egg hatch inhibition test was conducted under in-vitro conditions. For this, desired concentrations $(25,50,75$ and 100 percent) of 
culture filtrates were poured on the sterile cavity blocks containing 100 eggs per cavity block. Each treatment was replicated 3 times. Three control treatments were maintained, one as potato dextrose broth (PDB), second as nutrient broth (NB) medium and third as sterilized distilled water (SDW) were also maintained. Observations were recorded after 7days of exposure. For determining the hatching of eggs; test was conducted by transferring the tested eggs to sterile distilled water and observed egg hatching after $24 \mathrm{hrs}$ with the aid of stereomicroscope (x4). At the end of the experiment, number of unhatched eggs was calculated and per cent egg hatch inhibition calculated by using following formula:

Hatch inhibition of eggs $(\%)=$

Total number of eggs - Number of eggs hatched
Total number of eggs
$\times 100$

Efficacy of culture filtrates of antagonists on mortality of juveniles of Meloidogyne incognita

The mortality test was conducted under invitro conditions. For this, desired concentrations (25, 50, 75 and 100 per cent) of culture filtrates were poured on the sterile cavity blocks containing 100 juveniles $\left(\mathrm{J}_{2}\right)$ per cavity block. Observation on juvenile mortality was recorded at 24, 48, 72 and 96 hours of exposure. Apart from the treatments with different concentrations of antagonists, controls with potato dextrose broth (PDB), nutrient broth (NB) and sterilized distilled water (SDW) were also maintained. Each treatment was replicated 3 times. For determining the dead nematodes, revival test was conducted by transferring the immobile juveniles to sterile distilled water and observed their activities after $24 \mathrm{hrs}$. The juveniles that showed no movement even when they were probed with bamboo splinter were considered dead. The mortality (\%) was calculated using the formula give below.

Mortality $(\%)=$

$\begin{array}{llll}\text { Number of dead juveniles } & \text { in the treatment } \\ \text { Total number of juveniles } & \text { in the treatment }\end{array}$

100

\section{$\mathrm{LC}_{50}$ and $\mathrm{LT}_{50}$ values}

Mortality data thus obtained were subjected to 'Probit analysis' (Finney, 1952) to find out the $\mathrm{LC}_{50}$ and $\mathrm{LT}_{50}$ values against each antagonist at different time of exposure and at different concentrations.

\section{Statistical analysis}

The percentage values were subjected to the arcsin transformation before analysis and data were analyzed by using WASP - Web Agri Stat Package 2.0 version software. DMRT test was conducted to determine the significance of treatments. 'Probit analyses were performed by using IBM SPSS (Statistical Package for the Social Sciences) 20.0 version software.

\section{Results and Discussion}

Efficacy of culture filtrates of antagonists on the hatch inhibition of Meloidogyne incognita eggs

Statistical analysis (Table 1) shows that all the antagonists showed significant inhibition of egg hatching of $M$. incognita irrespective of concentration of the culture filtrates as compared to the control. No egg hatch inhibition was recorded in the controls (NB, PDB and SDW). At 25 percent concentration of culture filtrate, the maximum egg hatch inhibition was recorded in $P$. fluorescens $(39.50 \%)$ followed by $B$. megaterium 
$(36.25 \%)$ and both were significantly different from each other and also significantly different from rest of the treatments. This was followed by the treatment, Azotobacter sp. with inhibition of 26.75 per cent and this treatment was significantly different from rest of the treatments. Similarly, 13.75 per cent and 10.50 per cent inhibition were recorded in $P$. lilacinum and $P$. chlamydosporia respectively which were found to be significantly different from each other as also both were significantly different from Rhizobium sp. $(5.75 \%)$ where minimum egg hatch inhibition was recorded among all the treatments. At 50 percent concentration of culture filtrate, the maximum egg hatch inhibition was recorded in P. fluorescens (51.50\%) followed by $B$. megaterium (45.00\%), Azotobacter sp. (37.00\%), P. lilacinum (20.25\%), $P$. chlamydosporia (15.00\%). However, an egg hatch inhibition of 11.00 percent was recorded in the treatment with Rhizobium sp. All the treatments were significantly different from each other. A similar trend was observed at 75 and 100 percent concentration of the culture filtrates of antagonists.

\section{Efficacy of culture filtrates of antagonists on mortality of Meloidogyne incognita $\mathbf{J}_{2}$}

Statistical analysis (Table 2) shows that all the antagonists were found to be effective in causing mortality of $M$. incognita $\mathrm{J}_{2}$ irrespective of concentrations and time of exposure. All the antagonists showed significant increase in the mortality of $M$. incognita $\mathrm{J}_{2}$ irrespective of concentrations of the culture filtrates as compared to the controls. No mortality of $M$. incognita $\mathrm{J}_{2}$ was recorded in controls (NB, PDB and SDW). It observed that if the concentration of culture filtrate is increased there is corresponding increase in the mortality of $\mathrm{J}_{2}$ of $M$. incognita. However, all the antagonist were also found to be effective in causing mortality of $J_{2}$ with varying degrees at different concentrations of culture filtrates and at different exposure time. The relationship between the antagonists, concentration and time showed that all the tested antagonists were able to cause significant mortality of $M$. incognita $\mathrm{J}_{2}$ with increase in time of exposure and concentrations. However, the antagonists viz., $P$. lilacinum, $P$. chlamydosporia, Rhizobium spp., Azotobacter spp., B. megaterium and $P$. fluorescence showed maximum mortality of $\mathrm{J}_{2}$ in 100 percent concentration of culture filtrates at all the time of exposure. Among the antagonists, culture filtrate of the $P$. fluorescens was found to cause maximum mortality of $J_{2}$ in all the concentrations and at different time of exposure. P. fluorescens showed 35.67, 53.33, 63.67 and 75.00 percent mortality of $\mathrm{J}_{2}$ in $25,50,75$ and 100 percent concentration respectively after $96 \mathrm{hrs}$ of exposure and found to be the best bioagent. It is evident from the results that $P$. fluorescens was found to be the best among the antagonists.

\section{$\mathbf{L C}_{50}$ values}

The obtained juvenile mortality of $M$. incognita was subjected to probit analysis and it evaluated that the $\mathrm{LC}_{50}$ values (Table $3,4,5$ and 6) of culture filtrate of $P$. fluorescens against $\mathrm{J}_{2}$ of $M$. incognita were 128.33 , $125.41,64.84$ and 48.77 per cent at the exposure period of $24,48,72$ and $96 \mathrm{hrs}$ respectively. In case of $B$. megaterium the $\mathrm{LC}_{50}$ values were $142.59,133.22,89.73$ and 57.74 per cent at the exposure period of 24 , 48, 72 and 96 hrs respectively and that of Azotobacter sp. were 147.85, 133.34, 103.12 and 98.92 per cent at the exposure period of 24, 48, 72 and 96 hrs respectively. The $\mathrm{LC}_{50}$ values of $P$. lilacinum were $154.49,146.44$, 110.06 and 94.38 per cent at the exposure period of 24, 48, 72 and 96 hrs respectively while the $\mathrm{LC}_{50}$ values of $P$. chlamydosporia were $148.36,146.86,113.62$ and 103.16 per cent at the exposure period of 24, 48, 72 and $96 \mathrm{hrs}$ respectively. 
Table.1 Efficacy of culture filtrates of antagonists on the hatching of Meloidogyne incognita eggs

\begin{tabular}{|c|c|c|c|c|}
\hline \multirow[t]{2}{*}{ Treatments } & \multicolumn{4}{|c|}{ Concentration } \\
\hline & $25 \%$ & $50 \%$ & $75 \%$ & $100 \%$ \\
\hline \multirow[t]{2}{*}{ P. lilacinum } & 13.75 & 20.25 & 25.50 & 35.25 \\
\hline & $(21.76)_{\mathrm{d}}$ & $(26.74)_{d}$ & $(30.33)_{\mathrm{d}}$ & $(36.42)_{d}$ \\
\hline \multirow[t]{2}{*}{ P. chlamydosporia } & 10.50 & 15.00 & 22.50 & 34.00 \\
\hline & $(18.90)_{\mathrm{e}}$ & $(22.78)_{\mathrm{e}}$ & $(28.32)_{\mathrm{e}}$ & $(35.67)_{\mathrm{e}}$ \\
\hline \multirow[t]{2}{*}{ Rhizobium sp. } & 5.75 & 11.00 & 17.75 & 23.25 \\
\hline & $(13.87)_{\mathrm{f}}$ & $(19.37)_{\mathrm{f}}$ & $(24.91)_{\mathrm{f}}$ & $(28.83)_{\mathrm{f}}$ \\
\hline \multirow[t]{2}{*}{ Azotobacter sp. } & 26.75 & 37.00 & 46.00 & 53.25 \\
\hline & $(31.14)_{\mathrm{c}}$ & $(37.46)_{c}$ & $(42.71)_{c}$ & $(46.86)_{c}$ \\
\hline \multirow[t]{2}{*}{ B. megaterium } & 36.25 & 45.00 & 65.75 & 72.00 \\
\hline & $(37.02)_{\mathrm{b}}$ & $(42.13)_{\mathrm{b}}$ & $(54.18)_{\mathrm{b}}$ & $(58.05)_{b}$ \\
\hline \multirow[t]{2}{*}{ P. fluorescens } & 39.50 & 51.50 & 77.25 & 80.25 \\
\hline & $(38.94)_{\mathrm{a}}$ & $(45.86)_{a}$ & $(61.51)_{\mathrm{a}}$ & $(63.62)_{\mathrm{a}}$ \\
\hline \multirow[t]{2}{*}{ PDB } & 0.00 & 0.00 & 0.00 & 0.00 \\
\hline & $(0.64)_{g}$ & $(0.64)_{\mathrm{g}}$ & $(0.64)_{\mathrm{g}}$ & $(0.64)_{\mathrm{g}}$ \\
\hline \multirow[t]{2}{*}{ NB } & 0.00 & 0.00 & 0.00 & 0.00 \\
\hline & $(0.64)_{g}$ & $(0.64)_{\mathrm{g}}$ & $(0.64)_{g}$ & $(0.64)_{\mathrm{g}}$ \\
\hline \multirow[t]{2}{*}{ SDW } & 0.00 & 0.00 & 0.00 & 0.00 \\
\hline & $(0.64)_{\mathrm{g}}$ & $(0.64)_{\mathrm{g}}$ & $(0.64)_{\mathrm{g}}$ & $(0.64)_{\mathrm{g}}$ \\
\hline S.Ed. \pm & 0.30 & 0.28 & 0.28 & 0.24 \\
\hline $\mathrm{CD}_{0.05}$ & 0.62 & 0.58 & 0.59 & 0.51 \\
\hline
\end{tabular}

Figures in the parenthesis are arc sin transformed values.

PDB- Potato dextrose broth, NB- Nutrient Broth, SDW- Sterilized distilled water

Means within columns separated by Duncan's Multiple range test CD at 5 per cent levels of probability. Means followed by the same letters in the column are not significantly different from each other based on Duncan's Multiple Range Test at 5 per cent levels of probability. 
Table.2 Efficacy of culture filtrates of antagonists on the mortality of second stage juveniles (J2) of M. incognita

\begin{tabular}{|c|c|c|c|c|c|c|c|c|c|c|c|c|c|c|c|c|}
\hline \multirow[t]{3}{*}{ Treatments } & \multicolumn{16}{|c|}{ Concentration } \\
\hline & \multicolumn{4}{|c|}{$25 \%$} & \multicolumn{4}{|c|}{$\mathbf{5 0 \%}$} & \multicolumn{4}{|c|}{$75 \%$} & \multicolumn{4}{|c|}{$100 \%$} \\
\hline & 24hrs & $48 \mathrm{hrs}$ & 72 hrs & $96 \mathrm{hrs}$ & $24 \mathrm{hrs}$ & $48 \mathrm{hrs}$ & $72 \mathrm{hrs}$ & $96 \mathrm{hrs}$ & $24 \mathrm{hrs}$ & $48 \mathrm{hrs}$ & 72 hrs & $96 \mathrm{hrs}$ & $24 \mathrm{hrs}$ & $48 \mathrm{hrs}$ & $72 \mathrm{hrs}$ & $96 \mathrm{hrs}$ \\
\hline \multirow[t]{2}{*}{ P. lilacinum } & 8.00 & 13.33 & 20.00 & 30.00 & 14.67 & 17.67 & 25.67 & 34.00 & 20.00 & 25.67 & 36.00 & 42.33 & 28.00 & 33.33 & 46.33 & 53.33 \\
\hline & $(16.43)_{\mathrm{d}}$ & $(21.41)_{c}$ & $(26.56)_{d}$ & $(33.21)_{\mathrm{d}}$ & $(22.52)_{c}$ & $(24.86)_{\mathrm{d}}$ & $(30.44)_{c}$ & $(35.67)_{d}$ & $(26.56)_{c}$ & $(30.44)_{\mathrm{d}}$ & $(36.87)_{\mathrm{d}}$ & $(40.59)_{\mathrm{d}}$ & $(31.95)_{\mathrm{d}}$ & $(35.26)_{d}$ & $(42.90)_{\mathrm{d}}$ & $\left(46.91_{d}\right.$ \\
\hline \multirow[t]{2}{*}{ P.chlamydosporia } & 6.00 & 11.33 & 18.00 & 28.67 & 11.33 & 16.33 & 24.00 & 33.67 & 17.67 & 23.00 & 34.00 & 40.00 & 27.33 & 32.33 & 44.67 & 50.33 \\
\hline & $(14.17)_{\mathrm{e}}$ & $(19.66)_{\mathrm{d}}$ & $(25.10)_{\mathrm{e}}$ & $(32.37)_{\mathrm{e}}$ & $(19.67)_{\mathrm{d}}$ & $(23.83)_{\mathrm{e}}$ & $(29.33)_{\mathrm{d}}$ & $(35.47)_{\mathrm{d}}$ & $(24.86)_{\mathrm{d}}$ & $(28.66)_{e}$ & $(35.67)_{\mathrm{e}}$ & $(39.23)_{\mathrm{e}}$ & $\left(31.52_{d}\right.$ & $(34.65)_{e}$ & $(41.94)_{\mathrm{e}}$ & $(45.19)_{\mathrm{e}}$ \\
\hline \multirow[t]{2}{*}{ Rhizobium sp. } & 2.00 & 9.00 & 15.33 & 23.33 & 5.00 & 11.00 & 20.00 & 28.00 & 9.33 & 16.33 & 25.67 & 34.00 & 15.00 & 21.33 & 30.33 & 38.33 \\
\hline & $(8.12)_{\mathrm{f}}$ & $(17.46)_{\mathrm{e}}$ & $(23.05)_{\mathrm{f}}$ & $(28.88)_{\mathrm{f}}$ & $(12.91)_{\mathrm{e}}$ & $(19.37)_{\mathrm{f}}$ & $(26.56)_{e}$ & $(31.95)_{e}$ & $(17.77)_{\mathrm{e}}$ & $(23.83)_{\mathrm{f}}$ & $(30.44)_{\mathrm{f}}$ & $(35.67)_{\mathrm{f}}$ & $(22.78)_{\mathrm{e}}$ & $(27.51)_{\mathrm{f}}$ & $(33.42)_{\mathrm{f}}$ & $(38.25)_{\mathrm{f}}$ \\
\hline \multirow[t]{2}{*}{ Azotobacter sp. } & 9.00 & 14.00 & 21.00 & 32.00 & 15.67 & 20.33 & 26.33 & 37.67 & 22.33 & 28.00 & 38.00 & 45.67 & 30.00 & 37.00 & 49.33 & 56.67 \\
\hline & $(17.46)_{c}$ & $(21.97)_{\mathrm{c}}$ & $(27.27)_{\mathrm{c}}$ & $(34.45)_{c}$ & $(23.32)_{b}$ & $(26.80)_{c}$ & $(30.87)_{\mathrm{c}}$ & $(37.86)_{c}$ & $(28.20)_{b}$ & $(31.95)_{\mathrm{c}}$ & $(38.06)_{c}$ & $(42.52)_{\mathrm{c}}$ & $(33.21)_{\mathrm{c}}$ & $(37.46)_{\mathrm{c}}$ & $(44.62)_{\mathrm{c}}$ & $(48.83)_{\mathrm{c}}$ \\
\hline \multirow[t]{2}{*}{ B. megaterium } & 10.33 & 18.33 & 24.00 & 38.00 & 15.00 & 25.00 & 34.67 & 46.67 & 23.00 & 31.67 & 44.33 & 57.33 & 32.33 & 39.00 & 53.67 & 64.33 \\
\hline & $(18.74)_{b}$ & $(25.35)_{b}$ & $(29.33)_{b}$ & $(38.06)_{a}$ & $\left(22.78_{b}\right)_{c}$ & $(30.00)_{b}$ & $(36.07)_{b}$ & $(43.09)_{\mathrm{b}}$ & $(28.66)_{b}$ & $(34.25)_{b}$ & $(41.74)_{b}$ & $(49.22)_{\mathrm{b}}$ & $(34.65)_{b}$ & $(38.65)_{b}$ & $(47.10)_{b}$ & $(53.33)_{\mathrm{b}}$ \\
\hline \multirow[t]{2}{*}{ P. fluorescens } & 12.33 & 22.33 & 29.00 & 35.67 & 19.00 & 30.00 & 43.00 & 53.33 & 28.67 & 36.00 & 55.33 & 63.67 & 37.00 & 42.00 & 68.00 & 75.00 \\
\hline & $(20.55)_{a}$ & $(28.20)_{\mathrm{a}}$ & $(32.58)_{a}$ & $\left(36.67_{b}\right.$ & $(25.84)_{a}$ & $(33.21)_{\mathrm{a}}$ & $(40.98)_{a}$ & $(46.91)_{a}$ & $(32.37)_{a}$ & $(36.87)_{a}$ & $(48.06)_{a}$ & $(52.93)_{\mathrm{a}}$ & $(37.46)_{a}$ & $(40.40)_{\mathrm{a}}$ & $(55.55)_{a}$ & $(60.00)_{a}$ \\
\hline \multirow[t]{2}{*}{ PDB } & 0.00 & 0.00 & 0.00 & 0.00 & 0.00 & 0.00 & 0.00 & 0.00 & 0.00 & 0.00 & 0.00 & 0.00 & 0.00 & 0.00 & 0.00 & 0.00 \\
\hline & $(0.64)_{g}$ & $(0.64)_{\mathrm{f}}$ & $(0.64)_{g}$ & $(0.64)_{g}$ & $(0.64)_{\mathrm{f}}$ & $(0.64)_{g}$ & $(0.64)_{\mathrm{f}}$ & $(0.64)_{\mathrm{f}}$ & $(0.64)_{\mathrm{f}}$ & $(0.64)_{g}$ & $(0.64)_{g}$ & $(0.64)_{g}$ & $(0.64)_{\mathrm{f}}$ & $(0.64)_{g}$ & $(0.64)_{g}$ & $(0.64)_{g}$ \\
\hline \multirow[t]{2}{*}{ NB } & 0.00 & 0.00 & 0.00 & 0.00 & 0.00 & 0.00 & 0.00 & 0.00 & 0.00 & 0.00 & 0.00 & 0.00 & 0.00 & 0.00 & 0.00 & 0.00 \\
\hline & $(0.64)_{g}$ & $(0.64)_{\mathrm{f}}$ & $(0.64)_{g}$ & $(0.64)_{g}$ & $(0.64)_{\mathrm{f}}$ & $(0.64)_{g}$ & $(0.64)_{\mathrm{f}}$ & $(0.64)_{\mathrm{f}}$ & $(0.64)_{\mathrm{f}}$ & $(0.64)_{\mathrm{g}}$ & $(0.64)_{g}$ & $(0.64)_{g}$ & $(0.64)_{\mathrm{f}}$ & $(0.64)_{g}$ & $(0.64)_{g}$ & $(0.64)_{g}$ \\
\hline \multirow[t]{2}{*}{ SDW } & 0.00 & 0.00 & 0.00 & 0.00 & 0.00 & 0.00 & 0.00 & 0.00 & 0.00 & 0.00 & 0.00 & 0.00 & 0.00 & 0.00 & 0.00 & 0.00 \\
\hline & $(0.64)_{\mathrm{g}}$ & $(0.64)_{\mathrm{f}}$ & $(0.64)_{g}$ & $(0.64)_{\mathrm{g}}$ & $(0.64)_{\mathrm{f}}$ & $(0.64)_{\mathrm{g}}$ & $(0.64)_{\mathrm{f}}$ & $(0.64)_{\mathrm{f}}$ & $(0.64)_{\mathrm{f}}$ & $(0.64)_{g}$ & $(0.64)_{g}$ & $(0.64)_{g}$ & $(0.64)_{\mathrm{f}}$ & $(0.64)_{g}$ & $(0.64)_{g}$ & $(0.64)_{g}$ \\
\hline S.Ed. \pm & 0.31 & 0.29 & 0.27 & 0.22 & 0.32 & 0.28 & 0.25 & 0.21 & 0.36 & 0.21 & 0.18 & 0.22 & 0.22 & 0.21 & 0.20 & 0.21 \\
\hline $\mathrm{CD}_{0.05}$ & 0.65 & 0.62 & 0.57 & 0.47 & 0.67 & 0.59 & 0.52 & 0.44 & 0.76 & 0.44 & 0.39 & 0.46 & 0.46 & 0.44 & 0.43 & 0.44 \\
\hline
\end{tabular}

Figures in the parenthesis are arc sin transformed values.

PDB- Potato dextrose broth, NB- Nutrient Broth, SDW- Sterilized distilled water within columns separated by Duncan's Multiple range test CD at 5 per cent levels of probability. Means followed by the same letters in the column are not significantly different from each other based on Duncan's Multiple Range Test at 5 per cent levels of probability. 
Table.3 LC50 values of culture filtrates of different antagonists to J2 of Meloidogyne incognita after 24 hrs of exposure

\begin{tabular}{|c|c|c|c|c|c|}
\hline Treatments & $\mathrm{LC}_{50}$ value & $\begin{array}{l}\text { Fiducial limit } \\
\text { (Lower- Upper) }\end{array}$ & $\begin{array}{l}\text { Heterogeneity } \\
\qquad\left(\mathbf{R}^{2}\right)\end{array}$ & $\begin{array}{c}\text { Standard error } \\
\text { of regression } \\
\text { coefficient }\end{array}$ & Regression equation \\
\hline P. lilacinum & 154.49 & $135.52-192.13$ & 0.925 & 0.101 & $Y=1.606+0.011 X$ \\
\hline P. chlamydosporia & 148.36 & $130.92-177.62$ & 0.946 & 0.127 & $Y=1.854+0.012 X$ \\
\hline Rhizobium sp. & 177.96 & $151.68-228.18$ & 0.912 & 0.168 & $Y=2.326+0.013 X$ \\
\hline Azotobacter sp. & 147.85 & $108.71-181.41$ & 0.969 & 0.114 & $Y=1.571+0.002 X$ \\
\hline B. megaterium & 142.59 & $125.07-172.44$ & 0.650 & 0.113 & $Y=1.557+0.011 X$ \\
\hline P. fluorescens & 128.33 & $114.16-151.41$ & 0.953 & 0.107 & $\mathrm{Y}=1.427+0.011 \mathrm{X}$ \\
\hline
\end{tabular}

$\mathrm{Y}=$ Probit Kill, $\mathrm{X}=\log$ dose

Mortality based on 3 replications each with $100 \mathrm{~J}_{2}$ of M. incognita.

Table.4 LC50 values of culture filtrates of different antagonists to J2 of Meloidogyne incognita after 48 hrs of exposure

\begin{tabular}{|c|c|c|c|c|c|}
\hline Treatments & $\mathbf{L C}_{50}$ value & $\begin{array}{c}\text { Fiducial limit } \\
\text { (Lower- Upper) }\end{array}$ & $\begin{array}{l}\text { Heterogeneity } \\
\qquad\left(\mathbf{R}^{2}\right)\end{array}$ & $\begin{array}{l}\text { Standard error of } \\
\text { regression } \\
\text { coefficient }\end{array}$ & Regression equation \\
\hline P. lilacinum & 146.44 & $126.02-184.11$ & 0.953 & 0.099 & $Y=1.362+0.009 X$ \\
\hline P. chlamydosporia & 146.86 & $127.32-181.73$ & 0.933 & 0.111 & $Y=1.475+0.010 X$ \\
\hline Rhizobium sp. & 205.11 & $163.05-306.99$ & 0.908 & 0.119 & $Y=1.562+0.008 X$ \\
\hline Azotobacter sp. & 133.34 & $116.89-161.72$ & 0.981 & 0.097 & $Y=1.329+0.001 \mathrm{X}$ \\
\hline B. megaterium & 133.22 & $114.41-169.02$ & 0.926 & 0.099 & $Y=1.099+0.008 X$ \\
\hline P. fluorescens & 125.41 & $106.89-162.69$ & 0.955 & 0.96 & $\mathrm{Y}=0.919+0.007 \mathrm{X}$ \\
\hline
\end{tabular}

$\mathrm{Y}=$ Probit Kill, $\mathrm{X}=\log$ dose

Mortality based on 3 replications each with $100 \mathrm{~J}_{2}$ of M. incognita. 
Table.5 LC50 values of culture filtrates of different antagonists to J2 of $M$. incognita after72 hrs of exposure

\begin{tabular}{|c|c|c|c|c|c|}
\hline Treatments & $\mathrm{LC}_{50}$ value & $\begin{array}{l}\text { Fiducial limit } \\
\text { (Lower- Upper) }\end{array}$ & $\begin{array}{l}\text { Heterogeneity } \\
\qquad\left(\mathbf{R}^{2}\right)\end{array}$ & $\begin{array}{l}\text { Standard error of } \\
\text { regression } \\
\text { coefficient }\end{array}$ & Regression equation \\
\hline P. lilacinum & 110.06 & $98.58-128.32$ & 0.950 & 0.098 & $Y=1.127+0.010 X$ \\
\hline P. chlamydosporia & 113.62 & $101.84-132.30$ & 0.948 & 0.100 & $Y=1.206+0.011 X$ \\
\hline Rhizobium sp. & 173.79 & $140.31-253.63$ & 0.779 & 0.104 & $Y=1.183+0.007 X$ \\
\hline Azotobactersp. & 103.12 & $92.35-117.84$ & 0.959 & 0.094 & $Y=1.126+0.011 X$ \\
\hline B. megaterium & 89.73 & $81.55-101.33$ & 0.948 & 0.094 & $Y=0.946+0.011 X$ \\
\hline P. fluorescens & 64.84 & $59.40-70.44$ & 0.977 & 0.093 & $Y=0.874+0.013 X$ \\
\hline
\end{tabular}

$\mathrm{Y}=$ Probit Kill, $\mathrm{X}=\log$ dose

Mortality based on 3 replications each with $100 \mathrm{~J}_{2}$ of $M$. incognita.

Table.6 LC50 values of culture filtrates of different antagonists to J2 of M. incognita after96 hrs of exposure

\begin{tabular}{|c|c|c|c|c|c|}
\hline Treatments & $\mathrm{LC}_{50}$ value & $\begin{array}{l}\text { Fiducial limit } \\
\text { (Lower- Upper) }\end{array}$ & $\begin{array}{c}\text { Heterogeneity } \\
\left(\mathbf{R}^{2}\right)\end{array}$ & $\begin{array}{l}\text { Standard error of } \\
\text { regression } \\
\text { coefficient }\end{array}$ & Regression equation \\
\hline P. lilacinum & 94.38 & $83.54-112.10$ & 0.924 & 0.092 & $Y=0.776+0.008 X$ \\
\hline P. chlamydosporia & 103.16 & $89.97-127.03$ & 0.934 & 0.093 & $Y=0.781+0.008 X$ \\
\hline Rhizobium sp. & 148.89 & $120.19-222.76$ & 0.881 & 0.096 & $Y=0.870+0.006 X$ \\
\hline Azotobactersp. & 98.92 & $84.41-128.27$ & 0.913 & 0.091 & $Y=0.616+0.006 X$ \\
\hline B. megaterium & 57.74 & $48.94-65.73$ & 0.968 & 0.090 & $Y=0.523+0.009 X$ \\
\hline P. fluorescens & 48.77 & $52.36-63.43$ & 0.944 & 0.091 & $Y=0.663+0.014 X$ \\
\hline
\end{tabular}

$\mathrm{Y}=$ Probit Kill, $\mathrm{X}=\log$ dose

Mortality based on 3 replications each with $100 \mathrm{~J}_{2}$ of M. incognita. 
Table.7 LT50 values of different antagonists to J2 of $M$. incognita at 25\% concentration of culture filtrates

\begin{tabular}{|c|c|c|c|c|c|}
\hline Treatments & $\mathbf{L T}_{50}$ value & $\begin{array}{l}\text { Fiducial limit } \\
\text { (Lower- Upper) }\end{array}$ & $\begin{array}{l}\text { Heterogeneity } \\
\qquad\left(\mathbf{R}^{2}\right)\end{array}$ & $\begin{array}{c}\text { Standard error of } \\
\text { regression } \\
\text { coefficient }\end{array}$ & Regression equation \\
\hline P. lilacinum & 139.76 & $122.96-168.06$ & 0.972 & 0.119 & $Y=1.701+0.012 X$ \\
\hline P. chlamydosporia & 137.81 & $122.54-162.62$ & 0.942 & 0.127 & $Y=1.879+0.014 X$ \\
\hline Rhizobium sp. & 138.34 & $124.09-161.04$ & 0.872 & 0.149 & $Y=2.226+0.016 X$ \\
\hline Azotobacter sp. & 135.86 & $120.02-162.19$ & 0.984 & 0.116 & $Y=1.656+0.012 X$ \\
\hline B. megaterium & 121.15 & $109.00-140.06$ & 0.950 & 0.111 & $Y=1.569+0.013 X$ \\
\hline P. fluorescens & 127.54 & $111.92-154.46$ & 0.923 & 0.105 & $\mathrm{Y}=1.335+0.01 \mathrm{X}$ \\
\hline
\end{tabular}

$\mathrm{Y}=$ Probit Kill, $\mathrm{X}=\log$ dose

Mortality based on 3 replications each with $100 \mathrm{~J}_{2}$ of M. incognita.

Table.8 LT50 values of different antagonists to J2 of $M$. incognita at 50\% concentration of culture filtrates

\begin{tabular}{|c|c|c|c|c|c|}
\hline Treatments & $\mathbf{L T}_{\mathbf{5 0}}$ value & $\begin{array}{c}\text { Fiducial limit } \\
\text { (Lower- Upper) }\end{array}$ & $\begin{array}{l}\text { Heterogeneity } \\
\left(\mathbf{R}^{2}\right)\end{array}$ & $\begin{array}{l}\text { Standard error of } \\
\text { regression } \\
\text { coefficient }\end{array}$ & Regression equation \\
\hline P. lilacinum & 142.23 & $121.73-181.66$ & 0.890 & 0.106 & $Y=1.316+0.106 X$ \\
\hline Rhizobium sp. & 144.37 & $120.00-133.92$ & 0.965 & 0.129 & $Y=1.937+0.014 X$ \\
\hline Azotobacter sp. & 132.83 & $115.04-165.14$ & 0.939 & 0.104 & $Y=1.275+0.01 X$ \\
\hline B. megaterium & 102.01 & $93.19-114.86$ & 0.964 & 0.102 & $Y=1.327+0.013 X$ \\
\hline
\end{tabular}

$\mathrm{Y}=$ Probit Kill, $\mathrm{X}=\log$ dose

Mortality based on 3 replications each with $100 \mathrm{~J}_{2}$ of M. incognita. 
Table.9 LT50 values of different antagonists to J2 of $M$. incognita at 75\% concentration of culture filtrates

\begin{tabular}{|c|c|c|c|c|c|}
\hline Treatments & $\mathbf{L T}_{\mathbf{5 0}}$ value & $\begin{array}{l}\text { Fiducial limit } \\
\text { (Lower- Upper) }\end{array}$ & $\begin{array}{c}\text { Heterogeneity } \\
\qquad\left(\mathbf{R}^{2}\right)\end{array}$ & $\begin{array}{l}\text { Standard error of } \\
\text { regression } \\
\text { coefficient }\end{array}$ & Regression equation \\
\hline P. lilacinum & 114.84 & $100.73-139.57$ & 0.923 & 0.098 & $Y=1.071+0.009 X$ \\
\hline P. chlamydosporia & 119.57 & $104.97-144.89$ & 0.935 & 0.100 & $Y=1.170+0.010 X$ \\
\hline Rhizobium sp. & 126.94 & $113.32-148.77$ & 0.956 & 0.113 & $Y=1.593+0.013 X$ \\
\hline Azotobacter sp. & 107.14 & $94.58-128.55$ & 0.963 & 0.096 & $\mathrm{Y}=0.901+0.009 \mathrm{X}$ \\
\hline B. megaterium & 82.64 & $76.20-91.08$ & 0.965 & 0.096 & $Y=1.073+0.013 X$ \\
\hline P. fluorescens & 68.09 & $62.69-74.13$ & 0.948 & 0.093 & $Y=0.920+0.014 X$ \\
\hline
\end{tabular}

$\mathrm{Y}=$ Probit Kill, $\mathrm{X}=\log$ dose

Mortality based on 3 replications each with $100 \mathrm{~J}_{2}$ of M. incognita.

Table.10 LT50 values of different antagonists to J2 of $M$. incognita at 100\% concentration of culture filtrates

\begin{tabular}{|c|c|c|c|c|c|}
\hline Treatments & $\mathbf{L T}_{50}$ value & $\begin{array}{c}\text { Fiducial limit } \\
\text { (Lower- Upper) }\end{array}$ & $\begin{array}{l}\text { Heterogeneity } \\
\left(\mathbf{R}^{2}\right)\end{array}$ & $\begin{array}{l}\text { Standard error of } \\
\text { regression } \\
\text { coefficient }\end{array}$ & Regression equation \\
\hline P. lilacinum & 86.16 & $77.45-99.07$ & 0.953 & 0.093 & $Y=0.841+0.010 X$ \\
\hline P. chlamydosporia & 92.94 & $82.60-109.68$ & 0.915 & 0.093 & $Y=0.837+0.009 X$ \\
\hline Rhizobium sp. & 123.55 & $108.76-148.77$ & 0.956 & 0.103 & $Y=1.284+0.010 X$ \\
\hline Azotobacter sp. & 77.66 & $70.00-87.99$ & 0.964 & 0.092 & $Y=0.757+0.010 X$ \\
\hline B. megaterium & 65.89 & $59.81-72.58$ & 0.962 & 0.092 & $Y=0.784+0.012 X$ \\
\hline P. fluorescens & 50.23 & $44.85-55.03$ & 0.917 & 0.092 & $Y=0.775+0.015 X$ \\
\hline
\end{tabular}

$\mathrm{Y}=$ Probit Kill, $\mathrm{X}=\log$ dose

Mortality based on 3 replications each with $100 \mathrm{~J}_{2}$ of M. incognita 
The $\mathrm{LC}_{50}$ values of Rhizobium sp. were 177.96, 205.11, 173.79 and 148.89 per cent for the exposure period of 24, 48, 72 and 96 hrs respectively. It was observed that the $\mathrm{LC}_{50}$ values were recorded to be lowest in $P$. fluorescens, thus it came out to be the most effective in causing the mortality of the $J_{2}$ of M. incognita.

\section{$\mathbf{L T}_{50}$ values}

The obtained juvenile mortality of $M$. incognita was subjected to probit analysis and it evaluated that the $\mathrm{LT}_{50}$ values (Table 7, 8, 9 and 10) of culture filtrate of $P$. fluorescens against $\mathbf{J}_{2}$ of $M$. incognita were $127.54,87.81$, 68.09 and $50.23 \mathrm{hrs}$ at the concentration of $25,50,75$ and 100 per cent respectively. In case of $B$. megaterium the $\mathrm{LT}_{50}$ values were 121.15, 102.01, 82.64 and $65.89 \mathrm{hrs}$ and Azotobacter sp. were 135.86, 132.83, 107.14 and $77.66 \mathrm{hrs}$ at the concentration of 25,50 , 75 and 100 per cent respectively. The $\mathrm{LT}_{50}$ value of $P$. lilacinum were 139.76, 142.23, 114.84 and $86.16 \mathrm{hrs}$ while the $\mathrm{LT}_{50}$ values of culture filtrate of $P$. chlamydosporia were 137.81, 135.00, 119.57 and $92.94 \mathrm{hrs}$ at the concentration of $25,50,75$ and 100 per cent respectively. The $\mathrm{LT}_{50}$ values of Rhizobium sp. were 138.34, 144.37, 126.94 and 123.55 hrs at the concentration of 25, 50, 75 and 100 per cent respectively. Thus, lowest $\mathrm{LT}_{50}$ values were recorded in $P$. fluorescens thereby came out to be most effective. In the present investigation, the culture filtrates of $P$. lilacinum showed more nematicidal activity than $P$. chlamydosporia. Similar type of observations were recorded by Hallman and Sikora, 1996, Kerry, 2000 and Annapurna et al., 2018 who reported that $P$. lilacinum showed more egg hatch inhibition and juvenile mortality of $M$. incognita under invitro conditions. However, among the tested antagonists, $P$. fluorescens showed more juvenile mortality and egg hatch inhibition of M. incognita in 25, 50,75 and 100 percent concentration of culture filtrate at 24, 48, 72 and $96 \mathrm{hrs}$ of exposure time. Siddiqui et al., 2001, Khan et al., 2002, and Khan et al., 2012 reported that filtrate of $P$. fluorescens caused more juvenile mortality and egg hatch inhibition of $M$. incognita than other tested antagonists, thus confirm the result of the present investigation. The fact that the culture filtrates in the present study were free of cells, spores and mycelia and strongly implies that the compounds in the filtrates had some toxic/ antibiotic substances that were found to be instrumental in causing the mortality of juvenile and egg hatch inhibition of $M$. incognita. Nitao et al., 1999 reported that an antagonist secretes nematicidal metabolites and enzymes that affect nematode viability. Indeed, Purpureocillium spp. secretes toxin like paecilotoxin (Mikami et al., 1988) and leucinostatins (Park et al., 2004), P. chlamydosporia produce lytic enzymes like esterase, chitinase and lipase in the culture filtrates (Esteves et al., 2009 ), Bacillus spp. produce endotoxin (Totora et al.,1980), bulbiformin (Brannen, 1995), Azotobacter spp. also releases the antibiotics, lytic enzymes and hydrocyanic acid in the medium (Van Loon et al., 1998 and Selvakumar et al., 2009) in the filtrates and that caused inhibition in egg hatch and induced the mortality of $\mathbf{J}_{2}$ of root-knot nematode. The eggs of nematode are semi-permeable in nature and due to this, nematode eggs facilitate certain molecules or ions to pass through it. So toxin had a permanent adverse effect on the eggs or there appears to be physical retention of the toxins in the eggs, as hatching was not resumed on the transfer of eggs in water after one day (Clark and Perry, 1988). The reason behind the actual cause of mortality of $M$. incognita $\mathrm{J}_{2}$ might be due to release of hydrogen cyanide, ammonia, phenazine, pyoleutorin, pyrrolnintrin (Whistler et al., 2000 and Schoonbeck et al., 2002), 2, 4- diacetyl phloroglucinol (Siddiqui and Shaukat, 2003) by the antagonist 
especially $P$. fluorescens and Khan et al., 2012 also reported that the antagonism of $P$. fluorescens may have occurred through the effects of hydrogen cyanide (HCN)/ ammonia (NH3) as the bacterium produced these nematoxic chemicals in culture broth, as a result, bring down mortality of $M$. incognita $\mathbf{J}_{2}$ in the filtrates. The variable effect of culture filtrates on $M$. incognita observed in the present investigation can be attributed to the varied nature of toxic metabolites produced by different species of antagonists.

\section{Acknowledgement}

The author is greatly thankful to Department of Plant Pathology and Department of Soil Science, Assam Agricultural University, Jorhat, Assam for providing the antagonists.

\section{References}

Annapurna, M., Bhagawati, B., and Kurulkar U. 2018. In-vitro efficacy of native fungal bioagents against Meloidogyne incognita. International Journal of Current Microbiology and Applied Science. 7(11): 396-410.

Anonymous. 2011. Three decades of nematology in Assam. AICRP on Plant parasitic nematodes with integrated approach for their control, Jorhat, Assam. pp-10.

Blaxster, M.L., and Robertson, W.M. 1998. The cuticle. Free-Living and Plant Parasitic Nematodes. Perry RN, Wright, DJ. CAB International, Wallingford, England, 25-48.

Brannen, R. 1995. Production of antibiotics by Bacillus subtilis and their effect on fungal colonies of various crops. Transactions of the British Mycological Society. 65: 203.

Clark, A.J., and Perry, N. 1988. The induction of permeability of egg shell of Ascaris suum prior to hatching. International
Journal of Parasitiology. 18: 987-990.

Esteves, I., Peteria, B., Atkins, S.D., and Kerry, B. 2009. Production of extracellular enzymes by different isolates of Pochonia chlamydosporia. Mycological Research. 113(8):867-876.

Finney, D. J. 1952. Probit Analysis. Cambridge University Press, London, 318.

Hallman, J., and Sikora, R.A. 1996. Toxicity of fungal endophyte secondary metabolites to plant-parasitic nematodes and soil borne plant pathogenic fungi. European Journal of Plant Pathology. 102: 155-162.

Irving, F., and Kerry, B.R. 1986. Variation between strains of the nematophagous fungus Verticillium chlamydosporium Goddard II. Factors affecting parasitism of cyst nematode eggs. Nematologica. 32:474-485.

Kerry, B.R. 2000. Rhizosphere interactions and exploitation of microbial agents for the biological control of plant parasitic nematodes. Annual Review of Phytopathology. 38: 423-441.

Khan, M. R., Khan, M. M., Anwer, M. A. and Haque, Z. 2012. Laboratory and field performance of some soil bacteria used as seed treatments on Meloidogyne incognita in chickpea. Nematologia Mediterranea. 40: 143-151.

Khan, M.S., Zaidi, A. and Aamil, M. 2002. Biocontrol of fungal pathogens by the use of plant growth promoting rhizobacteria and nitrogen fixing microorganisms. Journal of the Indian Botanical Society 81: 255-263.

Kok, C.J., papert, A., and Hok-A-Hin, C. H. 2001. Microflora of Meloidogyne egg masses: species composition, population density and effect on the biocontrol agent Verticillium chlamydosporium (Goddard). Nematology 3: 729-734.

Mikami, Y., Fukushima, K., Samson, R.A., Udagawa, S., and Arai, T. 1988. 
Paecilotoxins, etiological agents of fungal infection. Proc. $X^{\text {th }}$ ISHAM Congress, Barcelona. pp. 128-132.

Nitao, J.K., Meyer, S.L.F., and Chitwood, D.J. 1999. In-vitro assays of Meloidogyne incognita and Heterodera glycines for detection of nematodeantagonistic fungal compounds. Journal of Nematology. 31: 172-183.

Park, J.O. Hargreares, J.R., Mc Conville., and Sivasithamparam, K. 2004. Production of leucinostatins and nematicidal activity of Australian isolates of Paecilomyces lilacinus (Thom) Samson. Letters in Applied Microbiology. 38(4): 271-276.

Sahebani, N., and Hadavi, N 2008. Biological control of the root-knot nematode Meloidogyne javanica by Trichoderma harzianum. Soil Biology and Biochemistry. 40: 2016-2020.

Sánchez-Bayo, F. (2011). Insecticides mode of action in relation to their toxicity to non-target organisms. Journal of Environment Analytic Toxicology. 4: 19.

Schoonbeek, H., Raaijmakers, J.M., and Waard, M. A. De. 2002. Fungal ABC transporters and microbial interactions in natural environments. Molecular Biology and Pathogenicity of Mycoplasmas. 15: 1165-1172.

Selvakumar, G., Lenin, M., Thamizhiniyan, P., and Ravimycin, T. 2009. Response of biofertilizers on the growth and yield of black gram (Vigna mungo L.). Recent Research in Science and Technology. 1(4): 169-175.
Sharon, E., Bar, E. M., Chet, I., HerreraEstrella, A., Kleifeld, O., and Spiegel, Y. 2001. Biological control of the rootknot nematode Meloidogyne javanica by Trichoderma harzianum. Phytopathology. 91: 687-693.

Siddiqui, A.I., Ehteshamul-Haque, S., and Shaukat, S.H. 2001. Use of rhizobacteria in the control of root-rotroot-knot disease complex of mungbean. Journal of Phytopathology. 149: 337-346.

Siddiqui, I.A., and Shaukat, S.S. 2003. Supprpession of root knot disease by Pseudomonas fluorescens CHA0 in tomato: importance of bacterial secondary metabolite, 2, 4diacetylphologlucinol. Soil Biology and Biochemistry. 35: 1615-1623.

Singh, S., and Mathur, N. 2010. In-vitro studies of antagonistic fungi against the root-knot nematode, Meloidogyne incognita. Biocontrol Science and Technology. 20 (3): 275-282.

Totora, G.J., Funke, B.R., and Case, C.L. 1980. Microbiology. An introduction. Benjamin Cummings New York, $10^{\text {th }}$ edition. pp. 810.

Van Loon, L.C., Bakker, P.A., and Pieterse, C.M.J. 1998. Systemic resistance induced by rhizosphere bacteria. Annual Review of Phytopathology. 36: 453-483.

Whistler, C.A., Stockwell, V.O., and Loper, J.E. 2000. Lon protease influences antibiotic production and UV tolerance of Pseudomonas fluorescens Pf-5. Applied and Environmental Microbiology. 66: 2718-2725.

\section{How to cite this article:}

Arunima Bharali, Bhabesh Bhagawati and Kurulkar Uday. 2019. Nematicidal Toxicity of Native Antagonists against Meloidogyne incognita. Int.J.Curr.Microbiol.App.Sci. 8(02): 13851398. doi: https://doi.org/10.20546/ijcmas.2019.802.163 